\title{
EXAMINING THE NEED FOR A PUBLIC PROCUREMENT MATURITY MODEL (PPMM) FOR INFRASTRUCTURE BUYERS IN A MONOPSONY MARKET STRUCTURE
}

\begin{abstract}
Dr. Ec. Violeta Simionescu, MBA - lecturer for Economics with Technical University of Civil Engineering Bucharest, Teacher Training Department and Procurement Senior Consultant with Integrate Investment, e-mails: violeta.simionescu@utcb.ro, violeta.simionescu@in-in.ro
\end{abstract}

\section{Rezumat}

Aceasta lucrare analizează nevoia unui Model de Maturitate în Achizițiile Publice (PPMM) în organizațiile ce indeplinesc rolul de achizitori de infrastructura rutieră într-o piață de tip monopson. Mediul utilizat pentru a contextualiza informația este Romania și CNADNR (Compania Națională de Autostrăzi și Drumuri Naționale din România).

Literatura de specialitate, datele disponibile public sau propria experiență reprezinta date de intrare pentru cele patru părți ale lucrării: (i) contextul nevoii unui model de maturitate in achizitii publice, (ii) modele de maturitate în achiziții (publice) existente (iii) analiză, și (iv) rezumat, limitări și perspective.

Lucrarea oferă argumente pentru o intervenție in amonte în lanțul de creare a valorii in infrastructura rutiera si evidențiază beneficiile unei astfel de intervenții. Elemente precum dimensiunile culturale ale Romaniei, structura pieței sau efectul procesului de achiziții publice asupra infrastructurii rutiere sunt elemente relevante ale unei intervenții concepute să contribuie la îmbunătăţirea performanței procesului de achiziții.

Rezultatele acestei lucrări constituie un punct de plecare pentru reflecții asupra performantei în achizițiile publice de infrastructura rutiera din Romania. In plus fata de evidențierea nevoii unei intervenții la nivelul autorităţii contractante, lucrarea argumentează necesitatea includerii structurii pieței sau a dimensiunilor naționale culturale ca date de intrare in conceperea modelelor de maturitate.

Cuvinte cheie: achiziții publice de infrastructură rutieră, model de maturitate, monopson, dimensiuni culturale

\section{Abstract}

This paper examines the need for a Public Procurement Maturity Model (PPMM) in organizations with the role of road infrastructure buyers under public procurement legislation in a monopsony market structure. The environment used to contextualize the information is 


\author{
Violeta Simionescu \\ Examining the need for a public procurement maturity model (PPMM) for infrastructure buyers in a monopsony \\ market structure
}

Romania and CNADNR (Compania Naţională de Autostrăzi și Drumuri Naţionale din România).

The literature research, open data as well as my own practical experience are used as entry data for the four parts of the paper: (i) the context leading to the PPMM need identification, (ii) an overview of the existing public (procurement) maturity models; (iii) discussions and (iv) summary, limitations, and outlook.

The paper provides arguments of an upstream intervention in the value chain of road transport infrastructure and highlights the benefits of such an intervention. Elements such as Romanian cultural dimensions, type of market structure or impact of the outcomes of public procurement process for road infrastructure are considered relevant entry data for an intervention which aims to contribute to the improvement of performance at a procurement process level.

The results of this paper serve as a starting point for further reflection on the performance in road infrastructure public procurement area in Romania. In addition to the awareness of the need for an intervention at a contracting authority level, the paper arguments that market structure or national cultural dimensions must be considered as entry data in designing maturity models.

Keywords: Road Infrastructure Public Procurement, Maturity Model, Monopsony, Cultural Dimensions

\title{
1. DESCRIPTION OF THE CONTEXT LEADING TO THE NEED OF A PPMM
}

Under this headline several arguments supporting the need for an intervention are included. The arguments relate to (1) the behaviour of a buyer (contracting authority) in a monopsony market structure; (2) features of Romanian national and organizational culture and (3) the relevance of infrastructure public procurement for Romania from societal perspective.

\subsection{The behavior of a buyer (contracting authority) in a monopsony market structure}

„Buyer power” can take two different forms: „monopsony power” [14] and „bargaining power" [3].

Monopsony is characterized by a sole buyer that interacts with many would-be sellers of a particular product/service or by one very large and dominant buyer that faces little competition only from fringe buyers. Romanian roads infrastructure public procurement market includes a dominant buyer CNADNR - and small buyers (at each district level). 
ROMANIAN JOURNAL

OF TRANSPORT INFRASTRUCTURE

\author{
Violeta Simionescu \\ Examining the need for a public procurement maturity model (PPMM) for infrastructure buyers in a monopsony \\ market structure
}

For the public procurement policy area, „monopsony” market structure and „buyer power" represent constant concerns (in the literature but also in practice). Systematic concerns about the relationship between the degree of market competition and public procurement process outcomes and outputs are at the core of international attention (for egg. Organisation for Economic Cooperation and Development (OECD) [14], and the International Competition Network (ICN) [9].

Similar interests were identified also at a national level in different countries. For example a research commissioned in 2014, by the Office of Fair Trading (OFT) [27] in UK, highlighted the relation between the buyer power and the competition in the public procurement markets, generating a framework for discussions on how public procurement impacts on competition (buying power gives the contracting authority the opportunity to affect competition amongst its bidders). The research specifies in addition that buying power of a contracting authority may have knock-on effects in other markets. The Romanian Competition Council Report (2013) builds its demarche upon the general frame of the research report commissioned by OFT (UK). According to this report, the elements that characterize Romanian PP road infrastructure market are the following: (i) it is governed by "winner-takes-all" principle (contracts typically awarded to a single successful bidder); (ii) it is a bidding type market (iii) it is a monopsony market structure. In particular, the report highlights: „A buyer with high purchasing power on bidding markets has the capacity to influence the tendering process (price increases, scope of the tender and market entry facilitation) [...] The ability to change the rules of the tender may act either as a barrier against anticompetitive agreements or, on the contrary, can be an additional risk, an element that can foster buyer and some bidders' agreement" [19].

In Romania, a contracting authority as CNADNR enjoys buyer power as long as it is acting as contracting authority on road infrastructure public procurement market. Here are some of the reasons why this is happening: (i) high demand in infrastructure construction market; (ii) the relatively long duration of awarded contracts, which may benefit the winning bidder in terms of a guaranteed revenue stream; (iii) the high market entry barriers dictated through qualification criteria.

The buyer power of CNADNR is backed up by Romanian public procurement system features, which add to the complexity already generated by a monopsony market structure. Furthermore, some of the features which add to complexity are enumerated below for illustrative purposes. 
ROMANIAN JOURNAL

OF TRANSPORT INFRASTRUCTURE

\author{
Violeta Simionescu \\ Examining the need for a public procurement maturity model (PPMM) for infrastructure buyers in a monopsony \\ market structure
}

At the macro level (Romanian Public Procurement System) there are explicit, prescriptive, detailed and cumbersome instructions that require the contracting authorities (micro-level) to secure compliance with certain rules and legislation. Instead of encouraging buyers to seek value for money and compliance with Treaty on the Functioning of the European Union (TFUE) principles in the same time, the Romanian PP system leads to practices focused on doing things right instead of doing the right things.

OECD advocates the employment of an appropriate degree of transparency [15] in public procurement.

The primary Romanian public procurement is promoting a degree of transparency. However, the content regarding transparency provided by the secondary and tertiary legislation generates two effects that neutralize one another resulting in too much transparency that affects competition.

One positive effect is generated through the legal requirement for compulsory publication of the contract estimated value (quality of the information is not in discussion) both in contract notice and in contract award notice. Both general public and PP market benefit of such an increase in the transparency: economic operators can make better bidding decisions and the general public know how their money is being spent.

In parallel, there are transparency provisions employed in public procurement tertiary legislation which determines a negative impact on competition. Examples include but are not limited to bid price disclosure at the public bid opening or the obligation to disclose to the general public the coordinates of bidders submitting an offer. The negative impact on competition is also signalled by Romanian media and supervision bodies, especially in the form of failures in specific procurement exercises (such as bidders' collusion or improper risk allocation between contracting authority and contractor). These examples show how interventions performed at macro level, through public procurement regulations increase the transparency of the market but also might facilitate the collusion among bidders through the generation of constant interactions between them.

At micro level, any procurement exercise and especially the ones addressing a monopsony market are expected to benefit of a careful planning and of a contracting strategy. The contracting strategy is at the core of procurement planning process since it impacts directly on (i) the manner in which procurement process is performed and (ii) its output and outcome.

Ideally, in practice, a procurement exercise should secure (inter-alia), an appropriate balance between (i) alignment with the overall public procurement 
system policy objectives (i.e. transparency, anti-fraud, anti-bribery, value for money) and (ii) avoidance of a pro-collusion scenario.

Currently there is no public procurement legislation requiring explicitly the requirements mentioned above. In the absence of a prescriptive and explicit rule to be followed, there is no evidence that CNADNR (operating as an open social system) considers, during the procurement process planning stage, its buyer power, nor does it rely on predictions and contingencies to cope with its environment.

The lack of evidence in considering the dynamics of environment is due to many causes. I retain here only one: the influence of national cultural dimensions.

\subsection{Features of Romanian national and organizational culture}

The „culture” concept benefits of many definitions in the literature while the impact of culture on societies is subject of many researches. Two definitions are selected as relevant for the frame of this paper, namelly: (i) "the collective programming of the mind which distinguishes the members of one group or category of people from another" [8] and (ii) "the way in which a group of people solves problems"[24].

From the many researches showing the impact of culture on performance, two models are selected: (i) the Inglehart-Welzel Cultural Map, resulting from time series investigation of human beliefs and values over more than 30 years, published by World Values Survey (WVS) and (ii) the most referenced cultural value model associated to Hofstede's definition of culture, frequently used to describe cultures.

The figures below show the position of Romania in WVS Cultural map (fig. 1) and the score of Romania for each of the Hofstede's model on dimensions of national culture (fig. 2). 
ROMANIAN JOURNAL

OF TRANSPORT INFRASTRUCTURE

Violeta Simionescu

Examining the need for a public procurement maturity model (PPMM) for infrastructure buyers in a monopsony market structure

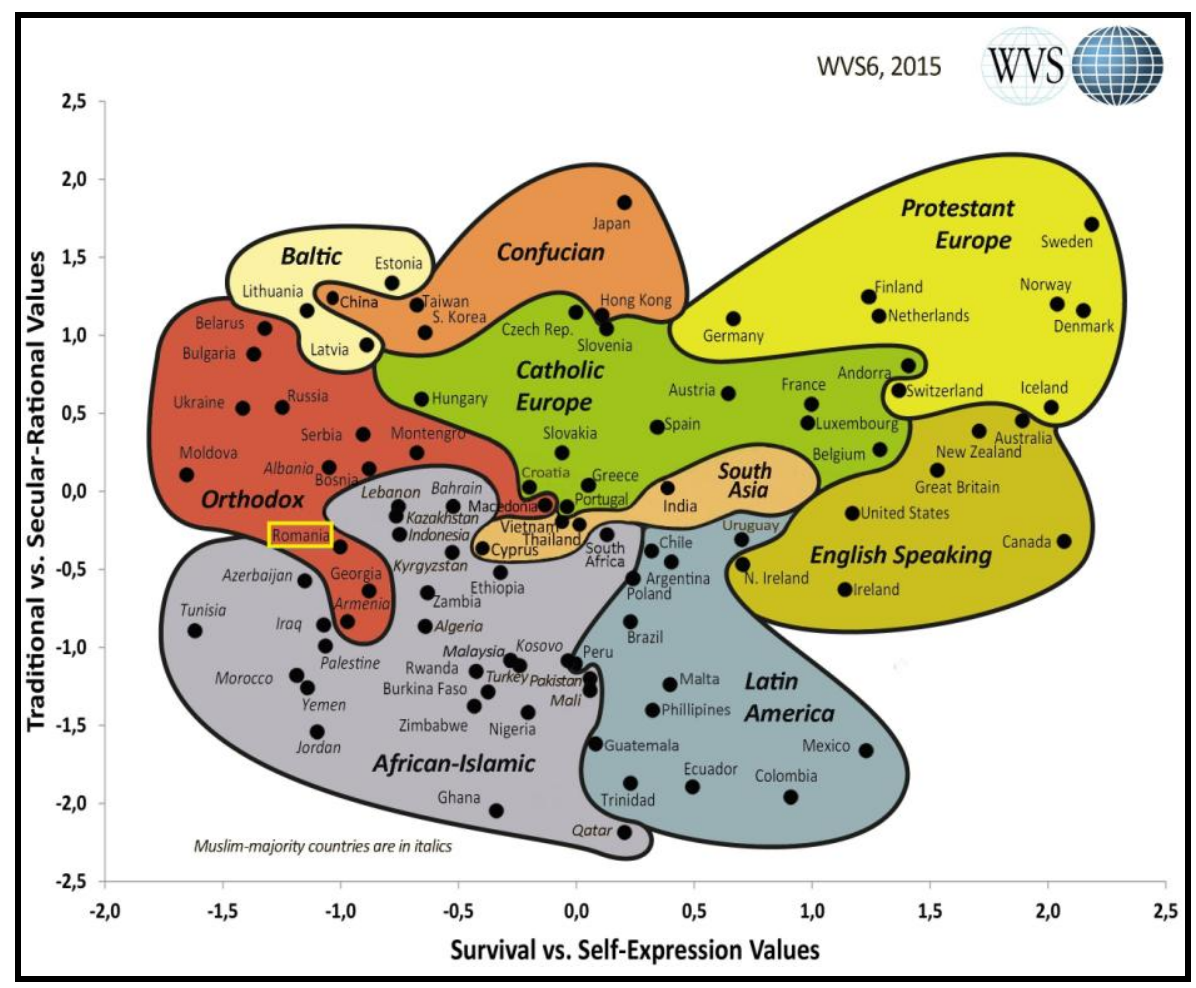

Figure 1. Inglehart-Welzel Cultural Map - World Values Survey (2015) [26]

„The WVS has over the years demonstrated that people's beliefs play a key role in economic development" [27]. On the map assessing two major dimensions of cross cultural variation in the world for 2010-2014, Romania ${ }^{1}$ scores negative on both dimensions. Features such as (i) the importance of deference to authority and (ii) the emphasis places on economic and physical security are linked, among others, with low levels of trust and tolerance, with low priority for environmental protection and with no pro-active demand for participation in decision-making in economic (and political) life.

\footnotetext{
1 The research for Romania was carried out by Metromedia Transilvania team composed by 3 principal investigators: Bogdan Voicu Senior researcher, Romanian Academy of Science, Research Institute for Quality of Life Associate professor, Department of Sociology, 'Lucian Blaga' University of Sibiu; Mircea Comşa Associate professor, Department of Sociology, Babeş-Bolyai University of Cluj; Claudiu Tufiş Assistant professor, Department of Political Science, University of Bucharest;
} 


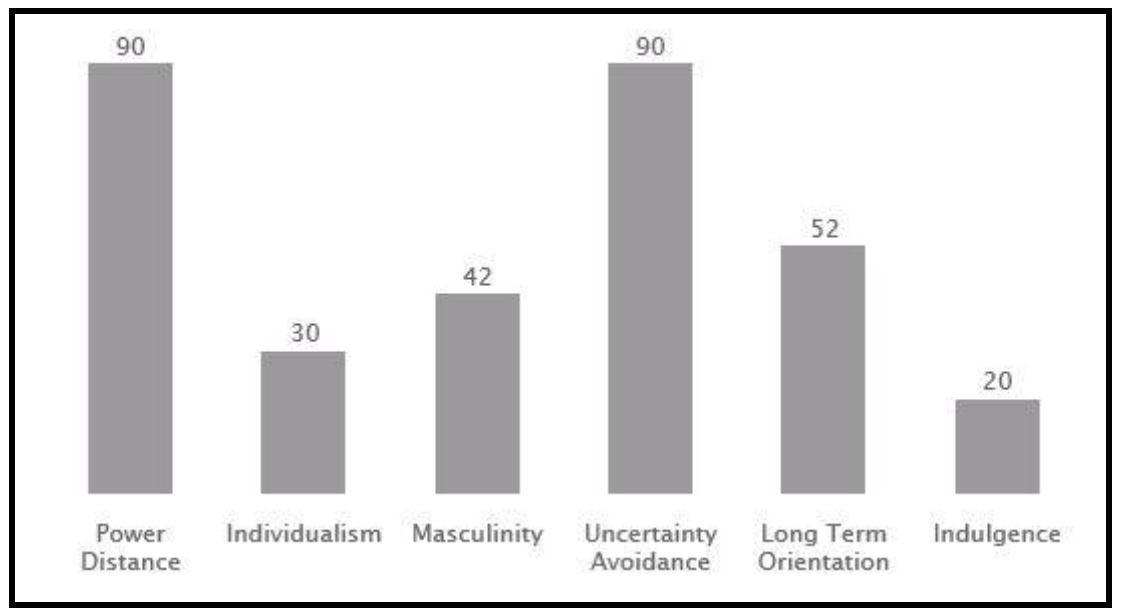

Figure 2. Romania's scores for the dimensions of national culture, based on the model developed by the validated research done by Professor Geert Hofstede, Gert Jan Hofstede, Michael Minkov [8]

Romania scores: (i) 90[8] on „Power Distance Index” dimension, which means that people accept a hierarchical order in which everybody has a place and needs no further justification; (ii) 30[8] on „Individualism” dimension, which is considered a collectivistic society and in which loyalty is paramount; (iii) 42[8] on "Masculinity" dimension and therefore the focus is on "working in order to live", managers strive for consensus, people value equality, solidarity and quality in their working lives; (iv) 90[8] on „Uncertainty Avoidance” dimension and thus has a very high preference for avoiding uncertainty; people have an inner urge to be busy and work hard, while innovation may be resisted; (v) 52 [8] on „Long Term Orientation” dimension being interpreted as being in an inception phase of a pragmatic approach namely encouraging efforts in modern education as a way to prepare for the future; (vi) 20 [8] on „Indulgence" dimension means people have the perception that their actions are restrained by social norms and feel that indulging themselves is somewhat wrong.

Romania benefits of specific national and organizational culture which impact on „doing business" behaviour. The specifics and dynamics of the culture become even more relevant in a government policy area, subject of rules which require appropriate degree of transparency and a continuous alignment with the dynamics of the environment. 
ROMANIAN JOURNAL

OF TRANSPORT INFRASTRUCTURE

Violeta Simionescu

Examining the need for a public procurement maturity model (PPMM) for infrastructure buyers in a monopsony

market structure

\subsection{The relevance of infrastructure public procurement for Romania}

The performance, the outputs and the outcomes of the public procurement in general and of road infrastructure public procurement in particular impact national competitiveness. According to OECD [13], the main determinants of competitiveness "pillars" included in Global Competitiveness Index [28] are linked with PP.

Europe 2020 Strategy requires the use of public procurement as an instrument designed for delivering smart, sustainable and inclusive growth [5]. Within this context, Council of European Union Recommendation for Romania [4] refers to: (i) „weak capacity of the public administration to develop and implement policies" which is ,hampering overall development of the country, the business environment and the capacity for public investment, while not allowing for the provision of public services of sufficient quality"; (ii) "Continuously weak management (....) and public procurement practices". According to EU Single Market Scoreboard: (i) the overall performance of Romania in PP in 2015 is below average, scoring unsatisfactory for first 4 out of the 6 dimensions [23], (ii) Romania ranks 28 out of 28 in the EU Transport Scoreboard 2015 for quality of roads, with a score of 2.75 points using a scale from 1 (extremely underdeveloped) to 7 (extensive and efficient) [22].

\section{OVERVIEW OF THE EXISTING (PROCUREMENT) MATURITY MODELS}

About 50 years ago, references to "maturity" indicating organizational capabilities were included in publications (see for instance Crosby, 1979), but earlier examples of maturity models can be identified, at individual level, in Maslow's hierarchy of human needs (1954) or Kuznets country's economic growth (1965) at society level. „Maturity” - treated from the organizational theory perspective - reflects ,the stage of development that an organization has reached or its ability to perform processes" [21]. The concept benefited of a large attention starting with the introduction of the Capability Maturity Model (1987).

Kohlegger, Maier and Thalmann (2009) state that "a maturity model conceptually represents phases of increasing quantitative or qualitative capability changes of a maturing element in order to assess its advances with respect to defined focus areas." [11] Maturity models are valuable instruments, 
ROMANIAN JOURNAL

OF TRANSPORT INFRASTRUCTURE

\author{
Violeta Simionescu \\ Examining the need for a public procurement maturity model (PPMM) for infrastructure buyers in a monopsony \\ market structure
}

even more valuable if they are of prescriptive nature: they can allow for the assessment of the current situation of a social system as well as the identification of improvement measures.

The maturing element may be a permanent or temporary social system, an object or an individual [11]. For the purpose of this paper only models consisting of a sequence of maturity levels for process as maturing element are of relevance.

Procurement is one of the processes performed by organizations. Kraljic (1983) emphasises the importance of procurement by recommending organizations to view procurement as a strategic rather than an operational function [12]. Porter (1985) depicted procurement as a support activity for the primary activities of an organization, and part of the value chain [17]. Nowadays, procurement is considered a strategic and relevant component of an organizational structure [25].

For the purpose of this paper, procurement - is defined as "the process of obtaining goods or services in any way, including purchasing, hiring, leasing and borrowing and would include as activities identification and definition of a business need; surveying the market to gather intelligence (e.g. on availability, price and technology developments); sourcing; (negotiation) and development of contracts, contract management, supplier relationship management, dispute resolution, contract review." This definition is promoted by Chartered Institute of Procurement \& Supply (CIPS), based on Lysons \& Farrington contribution.

The 2014 generation of PP Directives requires the same approach, specifying in the preamble that "The notion of acquisition should be understood broadly in the sense of obtaining the benefits of the works, supplies or services in question" [6]

Röglinger, Pöppelbuß, Becker (2010) identified in the academic or industry domains at least 10 process maturity models, which address either mastery of processes or mastery of process management [18]. However, for the specific area of public procurement maturity little evidence exists. During documentation for this paper, it has been found that public procurement maturity (if and when assessed) is assessed using MSU+ model, as derived from the Michigan State University (MSU) Model (of Monszka, 1999). Since its design in 2005 in Netherlands, MSU+ has been applied at around 50 contracting authorities.

It follows public procurement maturity model is an important construct considered both by practitioners and academic researchers. 


\section{DISCUSSIONS}

In the first part of the paper arguments for a PPMM and aspects to be addressed were presented. Furthermore, the magnitude of road infrastructure public procurement and associated performance has been highlighted, using dimensions such as level of expenditures, impact on national competitiveness or performance of Romania in comparison with EU Member States. The information is connected with the Romanian national and organizational culture, showing how these impacts on „doing business" behaviour or on the outputs and outcomes of the road infrastructure public procurement. It has been also highlighted that certain compliance degree in performing roads infrastructure public procurement can be impacted and secured using indirect channels such as legal and regulatory framework.

However, a closer relation between concepts such as sustainability, social return and best value for money and roads infrastructure public procurement can be construed only through interventions which both determine and explain the needed changes not only in hard area (process optimization) but also in the soft area (attitude, behaviour of people).

Currently no tool or method is systematically applied to cope with, or to manage, the complexity built by the environment (monopsony market structure and Romanian public procurement system features). The summarised elements of the Romanian PP system and the description of the specifics of the power of a contracting authority in a monopsony market structure justify the need for an intervention upstream in the chain of value creation, at the contracting authority level.

This need is underlined by other two environment dynamics. Firstly, the approach promoted by the 2014 generation of PP Directives content has an immediate implication on the need to recognize that, at micro level, procurement requires not only synchronization with other functions of the contracting authority at managerial level but also cross-functional procurement teams at operational level.

In addition, it highlights the importance of a well-functional organizational design [1] within the contracting authority, and the need to understand procurement as a multidisciplinary activity.

Secondly, the developments recorded for specifications, the scope of work and the service requirements tend become more rigorous [20] in parallel with the growth in technical complexity [7]. 
ROMANIAN JOURNAL

OF TRANSPORT INFRASTRUCTURE

\author{
Violeta Simionescu \\ Examining the need for a public procurement maturity model (PPMM) for infrastructure buyers in a monopsony \\ market structure
}

The existing academic international literature records to a large extend, information on the importance of procurement development within the context of a dynamic business environment. It also advocates and emphasizes value creation and delivery, integrated supply chain management or the strategic function of procurement.

For CNADNR - a contracting authority of „,national strategic interest", the quality of information included in the contracting strategy is of essence since CNADNR contracts about $1 \%$ of Romanian GDP or is involved in transactions representing about $10 \%$ of the yearly value of Romanian PP transactions in the last 3 financial years.

According to good practices, the contracting strategy is the result of a professional planning process, performed with consideration of environmental elements. The information must be processed using professional judgment of the procurement personnel through the eyes of the values and knowledge they possess. The contracting strategy sets the level of performance for a specific procurement process and it is also the reference used for performance evaluation of that single procurement exercise. It follows that there is a need to secure a certain level of performance, and this is possible only if appropriate orientation is provided.

CNADNR operates as an open system. Therefore, besides considering the monopsony market structure, a contracting authority such as CNADNR must rely on predictions and contingencies to cope with the environment. In doing so it is influenced by the cultural environment in which performs. In addition, the degree of closeness between public procurement and concepts such as sustainability, social return and best value for money is a national specificity, since it's influenced by different levels of understanding, cultural backgrounds and competencies obtained by procurement officers through the education system. In this case, the intervention must address also the influence of nation's cultural dimensions.

Considering the information above, and being aware of the advantages and limitations generated by particular characteristics of an organization acting as a buyer (contracting authority) under Romanian Public Procurement rules and by market structure constraints, the required intervention is suggested to take the form of a PPMM.

The intervention is suggested to be in the form of a PPMM, with the aim to assess and increase the maturity of the contracting authority in public

${ }^{2}$ According to CNADNR - Romanian National Company of Motorways and National Roads - http://www.cnadnr.ro; 
procurement performance, while providing orientation in a monopsony market environment.

The need to assess the maturity of the Romanian contracting authorities in the public procurement area is obvious (see, for instance the status of Romania's performance in public procurement described in EU Single Market Scoreboard). In addition, an understanding of current procurement maturity is a prerequisite for procurement to be perceived as a strategic function [10].

In the last years the lack of information on maturity of public procurement has been signalled [29]. Also, there are studies demonstrating a positive connection between the procurement maturity assessment and the performance. However, contracting authorities in the public procurement do not benefit from a system/model for measuring or improving the actual maturity in procurement [16].

The PPMM should be applied for ,as-is assessments” against pre-defined criteria [18] and should suggest improvement measures and actions using good or best practices (prescriptive nature, according to Röglinger, Pöppelbuß, Becker, 2012).

Procurement of road infrastructure is a large cost for the Romanian Government and Romania fails to manage the road infrastructure area. A maturity model, with which public procurement practitioners can assess their general practice and their public procurement process and process management maturity gives them orientation and help in understanding how they can improve. Romania, as a society, would benefit from such an action, not only in terms of public procurement costs, but also in terms of national competitiveness. Once the maturity model validated, it can be adapted for a larger spectrum of contracting authorities and used as a benchmark.

The PPMM must provide a performance measurement framework and must include dimensions which can secure the contracting authorities' contribution in terms of performance to the welfare of the society.

\section{SUMMARY, LIMITATIONS AND OUTLOOK}

This paper proposes an upwards intervention in the value chain creation for the road infrastructure public procurement in Romania, at the buyer level (CNADNR). The suggested form of intervention is a PPMM, which considers as entry data the specific features of the environment (monopsony market structure or Romania's national cultural dimensions). This paper is work in progress and 
therefore limited in scope. However, it argues that a PPMM construct must have, at least the following features:

i. Should be prescriptive in nature, in order to serve as an instrument for the assessment and development in the road infrastructure public procurement while providing guidance on improvement actions

ii. Should use as an unit of analysis the public procurement process, in order to allow for drill down into consideration of two sub-units:

1. the manner in which the process is organized and performed

2. the outputs and outcomes of the process and associated societal impact.

This drill down is required for securing an integrative approach which allows for a system perspective and acknowledgement of all facets of road infrastructure public procurement.

iii. Should be contextualised to the specifics of the environment in which a contracting authority performs, in order to not face constraints in model's applicability, while obtaining the maximum benefits in terms of improvements.

iv. Should include maturity levels scales.

Using as a reference the Procedure Model for the Development of Maturity Models and the associated requirements [2], within the exercise of elaborating this paper, 3 out of the set of 8 requirements are initiated:

v. Identification of Problem Relevance (R5)

vi. Problem Definition (R6)

vii. Comparison with existing maturity models (R1)

With the help of the existing maturity models in procurement, the relationships between procurement and other functions in an organization have been depicted. However, currently a statement that outlines how (public) procurement maturity leads to performance is not displayed [7].

Further developments are necessary in order to secure reasonable applicability of the requirements associated to the development of maturity models, in terms of initiated requirements, but also for the other 5 additional requirements (which address the development of model itself: R2 -Iterative Procedure, R3 - Evaluation, R4 -Multi-methodological Procedure, R7 Targeted Presentation of Results, R8 -Scientific Documentation).

The arguments presented in the first part of the paper are beset with some limitations. First, the arguments results from the reflection performed by the author and are based on personal findings. Therefore, additional arguments resulting from researches should be considered. Nevertheless, I covered part of the publically available information in terms of CNADNR performance as 
ROMANIAN JOURNAL

OF TRANSPORT INFRASTRUCTURE

\author{
Violeta Simionescu \\ Examining the need for a public procurement maturity model (PPMM) for infrastructure buyers in a monopsony \\ market structure
}

contracting authority. Second, in the review of the existing maturity models no specific maturity model was taken into account.

Future research on maturity models is required in order to access relevant existing public procurement maturity models, especially the ones designed for micro-level (contracting authorities). Nevertheless, there has been prior research dealing with public procurement maturity models, as specified under discussion headline. The current review did not identify to what extent the existing PPMM takes into account aspects such as cultural dimensions or monopsony power. As these elements also influence the usefulness of a maturity model, designing of a maturity model to address dimensions which examine the effects of these elements should be considered.

A PPMM considering the specific environment would provide benefits for the entire population of contracting authorities, but especially for contracting authorities performing procurement process (i) in a complex and dynamic environment; (ii) within a monopsony market; (iii) with impact on competitiveness of a nation; (iv) with outputs and outcomes directly linked to the fulfilment of a national policy and to Europe 2020 objectives.

In addition, for Romania, the existence of a PPMM could also reinforce support for the use of road infrastructure public procurement for the fulfilment of strategic objectives at societal level. Additional benefits would refer to contributions "per se" to a shift in the public procurement practice from the focus on „being seen" to have done things right to doing right things, while contributing to the amelioration of risk aversion amongst public procurement officers (as effect of improved capabilities).

\title{
REFERENCES
}

[1]. BJÖRN AXELSSON, ROZEMEIJER FRANK, WYNSTRA FINN: „Developing Sourcing Capabilities: Creating Strategic Change in Purchasing and Supply Management", Chichester, West Sussex, 2005.

[2]. BECKER, JORG KNACKSTEDT, RALF, PÖPPELBUß, JENS, Developing Maturity Models for IT Management, A Procedure Model and its Application 2009, available at http://link.springer.com/article/10.1007/s12599-009-0044-5/fulltext.html

[3]. CHEN, ZHIQI: „Buyer Power: Economic Theory and Antitrust Policy”, in Research in Law and Economic, Research in Law and Economics, Volume 22, Emerald Publishing, Bingley, 2007, available at http://www.emeraldinsight.com/doi/book/10.1016/S0193-5895\%282007\%2922. 
ROMANIAN JOURNAL

OF TRANSPORT INFRASTRUCTURE

\author{
Violeta Simionescu \\ Examining the need for a public procurement maturity model (PPMM) for infrastructure buyers in a monopsony \\ market structure
}

[4]. COUNCIL OF EUROPEAN UNION, COUNCIL RECOMMENDATION of 8 July 2014

on the National Reform Programme 2014 of Romania and delivering a Council opinion on the Convergence Programme of Romania, 2014/C 247/21 published in OJEU 247/109 on July 29, 2014.

[5]. EUROPEAN COMMISSION: "EUROPE 2020 A strategy for smart, sustainable and inclusive growth", Brussels, $\mathbf{2 0 1 0}$ available at http://eur-lex.europa.eu/legalcontent/EN/TXT/?uri=celex:52010DC2020.

[6]. EUROPEAN PARLIAMENT AND THE COUNCIL: Directive 2014/24/EU on public procurement and replacing directive 2004/18/EC, available at http://eurlex.europa.eu/legal-content/EN/TXT/?uri=uriserv:OJ.L_.2014.094.01.0065.01.ENG.

[7]. GADDE, LARS.-E., HAKANSSON, HAKAN., PERSSON, GORAN.: „Supply Network Strategies", Chichester, 2010.

[8]. HOFSTEDE, GEERT, HOFSTEDE, GERT JAN, MINKOV, MICHAEL: „Cultures and Organizations: Software of the Mind. Intercultural Cooperation and Its Importance for Survival”, 2010 Edition translated into Romanian „Culturi si organizatii: Softul mental. Cooperarea interculurala si importanta pentru supravietuire”, Humanitas, Bucuresti, 2012.

[9]. ICN: „Summary of ICN work product 2014-2015”, presented at the $14^{\text {th }}$ annual conference of the ICN, Sydney, Australia, April 29 - May 1, 2015, available at http://www.internationalcompetitionnetwork.org/uploads/library/doc1029.pdf.

[10]. KEOUGH, MARK: „Buying your way to the top”, McKinsey Quarterly 3, 1993, available

http://www.mckinsey.com/insights/operations/buying_your_way_to_the_top.

[11]. KOHLEGGER MICHAEL, MAIER RONALD, THALMANN STEFAN, "Understanding Maturity Models, Results of a Structured Content Analysis" Proceedings of I-KNOW '09 and I-SEMANTICS '09 2-4 September 2009, Graz, Austria, available http://iwi.uibk.ac.at/download/downloads/Publikationen/KMM.pdf

[12]. KRALJIC, PETER. (1983). Purchasing must become supply management. Harvard Business Review, No. 83509 SEPTEMBER-OCTOBER 1983, 61(5), 109-117, 1983

[13]. OECD: „Discussion paper on public procurement performance measures”, OECD Meeting of Leading Practitioners on Public Procurement, February 11-12, 2012, Paris, OECD Conference

Centre, available at 
ROMANIAN JOURNAL

OF TRANSPORT INFRASTRUCTURE

Violeta Simionescu

Examining the need for a public procurement maturity model (PPMM) for infrastructure buyers in a monopsony market structure

http://www.oecd.org/gov/ethics/Discussion\%20paper\%20on\%20public\%20procureme nt\%20performance\%20measures\%20GOV_PGC_ETH_2012_1.pdf.

[14]. OECD: „Policy Roundtables: Monopsony and Buyer Power”, 2008, (DAF/COMP (2008)38), available at: http://www.oecd.org/daf/competition/44445750.pdf.

[15]. OECD - Competition Division: "The OECD Checklist for Designing the Procurement Process to Reduce the Risk of Bid Rigging", Bucharest, 2012 presented within a seminar organized by Romanian Competition Council;

[16]. PLOMP, MARIJN G.A. AND BATENBURG, RONALD S: „Procurement Maturity, Alignment and Performance: a Dutch Hospital Case Comparison" in Proceedings of the $22^{\text {nd }}$ Bled eConference "eEnablement: Facilitating an Open, Effective and Representative eSociety", Bled, Slovenia, 2009, available at http://dspace.library.uu.nl/bitstream/handle/1874/40981/Plomp\%20\%26\%20Batenbur g\%20(2009)\%20Procurement\%20Maturity,\%20Alignment\%20and\%20Performance\% 20-\%20a\%20Dutch\%20Hospital\%20Case\%20Comparison.pdf?sequence=1;

[17]. PORTER, MICHAEL E: "Competitive Advantage: Creating and Sustaining Superior Performance”, New York, 1998.

[18]. RÖGLINGER MAXIMILIAN, PÖPPELBUß JENS, BECKER JÖRG Discussion Paper WI-352, Maturity Models in Business Process Management, in: Business Process Management Journal 18 (2012) 2, available at http://www.fimrc.de/Paperbibliothek/Veroeffentlicht/352/wi-352.pdf

[19]. ROMANIAN COMPETITION COUNCIL: „Investigatia sectoriala pe piata lucrarilor de constructii de drumuri si poduri", Romanian Competition Council Report for 2013, available at http://www.consiliulconcurentei.ro/uploads/docs/items/id8693/raport.pdf.

[20]. STANLEY, LINDA. L., WISNER, JOEL D.: „Service quality along the supply chain: implications for purchasing", Journal of Operations Management 19, 2001.

[21]. STUMMER, MICHAEL, GARREIS, ROLAND: „Business Process Management in the project oriented company", in Cleland, Di David., Gareis, R.: "Global Project Management Handbook”, McGraw-Hill, New York, 2006.

[22]. THE EU TRANSPORT SCOREBOARD, Romania, July 2015 Edition, available at http://ec.europa.eu/transport/facts-fundings/scoreboard/index_en.htm

[23]. THE EU SINGLE MARKET, "Single Market Scoreboard”, Romania, July 2014 Edition, available http://ec.europa.eu/internal_market/scoreboard/performance_by_member_state/romani a/index_en.htm. 
ROMANIAN JOURNAL

OF TRANSPORT INFRASTRUCTURE

Violeta Simionescu

Examining the need for a public procurement maturity model (PPMM) for infrastructure buyers in a monopsony market structure

[24]. Trompenaars, F., Hampden-Turner, C. Riding the waves of culture: understanding diversity in global business, 2nd ed. New York: McGraw Hill, 1998

[25]. VAN WEELE, ARJAN: „Purchasing \& Supply Chain Management: Analysis, Strategy, Planning and Practice”, London, 2005

[26]. WORLD VALUES SURVEY: “Inglehart-Welzel Cultural Map (2015)" available at http://www.worldvaluessurvey.org/WVSNewsShow.jsp?ID=192.

[27]. WORLD VALUES SURVEY FINDINGS available at: http://www.worldvaluessurvey.org/WVSContents.jsp?CMSID=Findings

[28]. WORLD ECONOMIC FORUM: The Global Competitiveness Report 2014-2015, assesses the competitiveness landscape of 144 economies, providing insight into the drivers of their productivity and prosperity. http://www.weforum.org/reports/globalcompetitiveness-report-2014-2015

[29]. ZHENG, JURONG; KNIGHT, LOUISE; HARLAND, CHRISTINE; HUMBY, STUART; JAMES, KEN: "An analysis of research on the future of purchasing and supply management", in Journal of purchasing and supply management, Vol. 13, No. 1, 01.2007, pg 69-83 